\title{
Research Article \\ MOLECULAR AND ANTIBODY BASED DIAGNOSIS OF DUCK PLAGUE VIRUS FROM FIELD OUTBREAKS IN ASSAM, INDIA
}

\author{
DOLEY M.K. .1 , DAS S.K. ${ }^{2}$, BARMAN N.N. ${ }^{2}$ AND BARUAH N. ${ }^{3}$ \\ 1ICAR-Krishi Vigyan Kendra, Karbi Anglong, Assam Agricultural University, Diphu, 782462, India \\ 2Department of Veterinary Microbiology, Assam Agricultural University, Guwahati, 781022, India \\ ${ }^{3}$ Regional Agricultural Research Station, Assam Agricultural Research Station, Diphu, 782462, India \\ *Corresponding Author: Email- monujdoley201039@gmail.com
}

Received: May 15, 2018; Revised: May 26, 2018; Accepted: May 27, 2018; Published: May 30, 2018

\begin{abstract}
The study was undertaken to detect duck plague virus by PCR and antibody-based techniques. A total of 79 samples were collected from clinically affected (40) and dead ducks (39). PCR detects presence of the virus in $85.00 \%$ and $87.17 \%$ from clinically affected and dead birds respectively. Among the antibody-based techniques, S-ELISA was found more sensitive in comparison to other tests showing positive results $32.05 \%$ and $71.79 \%$ from clinically affected and dead birds respectively. AGPT and CIE could detect the virus only in post mortem samples. Both AGPT and CIE were found to be equally sensitive giving positive result of $12.82 \%$ from dead ducks. Liver and spleen samples from dead birds were found best for pathogen detection. In cases of clinically affected ducks, whole blood showed to be better results than the cloacal swabs.
\end{abstract}

Keywords- Duck plague virus, DPV, S-ELISA, AGPT, CIE, PCR

Citation: Doley M.K., et al., (2018) Molecular and Antibody Based Diagnosis of Duck Plague Virus from Field Outbreaks in Assam, India. International Journal of Microbiology Research, ISSN: 0975-5276 \& E-ISSN: 0975-9174, Volume 10, Issue 5, pp.-1220-1223. DOl: http://dx.doi.org/10.9735/0975-5276.10.5.1220-1223

Copyright: Copyright@2018 Doley M.K., et al., This is an open-access article distributed under the terms of the Creative Commons Attribution License, which permits unrestricted use, distribution and reproduction in any medium, provided the original author and source are credited.

Academic Editor / Reviewer: Dr Bern Ozbek Celik

\section{Introduction}

Duck plague (DP) also known as duck virus enteritis (DVE) is an acute and contagious fatal viral infection of ducks, geese, swans and all other species of the order Anseriformes [1]. The disease is caused by Anatid herpesvirus 1, which is currently grouped in the alphaherpesvirinae subfamily of the Herpesvirus family [2]. In duck-producing areas of the world where the epornotic could be spread through international trade and natural migration of birds, resulting in significant economic losses in domestic and wild waterfowl [3]. As in case of other diseases of birds, the success of any control program mostly depends on availability of highly specific, rapid, and reliable diagnostic tests. A number of antibody based diagnostic tests like serum neutralization, immune-peroxidase, and immunefluorescence are used for diagnosis of duck plague virus (DPV). But these are found to be time consuming and labour intensive. So, there is a need to utilize some specific, rapid, reliable diagnostic tests like immune-diffusion, counter immune-electrophoresis tests for diagnosis of duck diagnosis of duck plague virus (DPV). But these are found to be time consuming and labour intensive. So, there is a need to utilize some specific, rapid, reliable diagnostic tests like immunediffusion, counter immune-electrophoresis tests for diagnosis of duck virus enteritis infection. Although these two tests were used for diagnosis of Duck Plague, in Assam no attempt was made earlier to use these two tests for screening samples prior to isolation of virus. Now-a-days PCR has been widely used in many diagnostic laboratories by various workers because of its high level of sensitivity and specificity and the fact that results can be obtained quickly, Although, some serological diagnostic tests were used for diagnosis of DPV from different outbreaks of Assam, no attempt has been made to use molecular diagnostic test like Polymerase Chain Reaction (PCR) for diagnosis of DPV infection, hence the present study has been undertaken.

\begin{abstract}
Materials and Methods
Collection of samples

During the period from February 2011 to May 2012 duck plague outbreaks in certain districts of Assam were attended. Clinical samples like cloacal swab and whole blood were collected from suspected cases of duck plague. Swabs were collected in sterile tube containing sterile Hank's balanced salt solution and whole blood was collected in EDTA. The collected samples were transported in ice and stored at $-20^{\circ} \mathrm{C}$ until further use. Ducks died of suspected DPV infection were subjected for post mortem examination and all organs were thoroughly examined for presence of typical DP lesions. Samples like liver, Spleen, kidney, oesophagus were collected in sterile vials without adding any preservatives as well as in 50 phosphate buffer glycerin and transported to the laboratory in ice.
\end{abstract}

\section{Detection of duck plague virus antigen and nucleic acid}

Duck plague viral antigen was detected in the tissue samples as well as clinical samples by Sandwich-ELISA, Agar gel precipitation test (AGPT), Counter Electrophoresis (CIE) and amplification of nucleic acid was done by Polymerase chain reaction (PCR).

\section{Sandwich ELISA (S-ELISA)}

S-ELISA was used to detect the DPV antigen as per the method [4] with modification. Briefly, rabbit anti-DPV antibody (1:500) coated wells were preblocked with blocking buffer containing $5 \%$ skim milk followed by incubation for 1h each with test antigen (20\% tissue homogenate/clocal swab) and then duck anti-DPV antibody (1:3000) diluted in blocking buffer was used as tracing antibody. Anti-duck HRPO conjugate (1:200) dilution was added and development of color observed by adding chromogen substrate solution. 
In each plate, chicken embryo adapted duck plague vaccine virus as positive control as well as uninfected CAM suspension as negative antigen control were run along with the test samples. The cut-off $O D$ value $(O D$ value of test samplesOD of negative control) 0.1 in the highest dilution of each samples was considered as positive.

\section{Agar gel precipitation test (AGPT)}

AGPT was done as per the methods [5] with slide modification. In this test the hyper immune serum raised in duck as well as rabbit against DPV vaccine strain were used as known antibody. The gel for AGPT was prepared by dissolving 0.9 percent agarose and 8 percent sodium chloride in acetate $(\mathrm{pH}$ 5.6) and phosphate buffer saline ( $\mathrm{pH}$ 7.2). On each slide, $5 \mathrm{ml}$ of the melted agarose were used and two sets wells $(3 \mathrm{~mm})$ were punched. The central wells were filled with $25 \mu \mathrm{l}$ of hyper immune serum and peripheral wells with suspension sample of DPV infection. The slides were kept at room temperature $\left(25-27{ }^{\circ} \mathrm{C}\right)$ for $24-48 \mathrm{~h}$ and then observed for precipitation lines. Positive slides were washed, dried and stained with 1 percent Coomassie brilliant blue for 25 min and then de-stained with distaining solution for $10 \mathrm{~min}$.

\section{Counter Immuno Electrophoresis}

$\mathrm{CIE}$ was also performed for detection of duck plague virus antigen from clinical as well as post mortem samples. A $0.9 \%$ agarose gel was prepared in acetate buffer and tris borate buffer. Hyper immune serum raised in duck as well as rabbit against DPV vaccine strain were used as known antibody. After loading of the antigen and the antibody, the clear precipitation band could be observed after running the gel at $45 \mathrm{~V}$ for one and half hour at room temperature. During the $\mathrm{CIE}$, normal uninfected CAM was also kept as negative control.

\section{Polymerase chain reaction (PCR)}

Extraction of viral DNA from the clinical samples post mortem samples as well as from the vaccine strain was done using Tissue and blood DNA extraction kit (Qiagen, Genetix). The procedure used for extraction of the viral DNA was as per manufacturer's recommendations. Extracted DNA samples were properly labelled and stored at $-20^{\circ} \mathrm{C}$ until use. The PCR was standardized using freeze dried duck plague vaccine virus as known DP viral DNA to amplify DNA directed DNA polymerase gene as per the method [6]. The sequence of the primer used in the PCR were primer I 5'-GAA-GGC-GGG-TAT-GTA-ATG-TA-3' (nucleotide position 55501-55520), Primer I| 5'-CAA-GGC-TCT-ATT-CGG-TAA-TG-3' (nucleotide position 55946- 55965). The PCR was performed in 50 $\mu$ l reaction volume containing 10X buffer $5 \mu \mathrm{l}, 25 \mathrm{mmol} \mathrm{MgCl}_{2} 3 \mu \mathrm{l}, 10 \mathrm{mmol}$ dNTP $1 \mu \mathrm{l}$, Taq polymerase (5unit/1 $\mu \mathrm{l}) 0.5 \mu \mathrm{l}$, Forward primer (20pmol) $1 \mu \mathrm{l}$, Reverse primer (20pmol) $1 \mu$ l, DNA template $5 \mu \mathrm{l}$ and nuclease free water in a final volume of $50 \mu \mathrm{l}$. The reaction was carried out for 37 cycles in a thermal cycler. The PCR cycles were consisting of three sets of cycles. The first set of PCR cycles consist of initial denaturation at $94^{\circ} \mathrm{C}$ for $2 \mathrm{~min}$, initial annealing $37^{\circ} \mathrm{C}$ for $1 \mathrm{~min}$ and initial extension at $72^{\circ} \mathrm{C}$ for 3 min followed by second sets of 35 numbers of PCR cycles consist of denaturation at $94^{\circ} \mathrm{C}$ for $1 \mathrm{~min}$, annealing at $55^{\circ} \mathrm{C}$ for $1 \mathrm{~min}$ and extension at $72^{\circ} \mathrm{C}$ for $2 \mathrm{~min}$. Final extension of the PCR cycles was done at $72{ }^{\circ} \mathrm{C}$ for $7 \mathrm{~min}$. The normal uninfected tissue DNA was kept as negative control. The amplified PCR products were stored at $-20^{\circ} \mathrm{C}$ until confirmed the gel electrophoresis. After PCR, the amplified products were confirmed by agarose gel electrophoresis using $1.7 \%$ agarose gel containing ethidium bromide in $0.5 \mathrm{X}$ tris borate EDTA (TBE) buffer. At the end of electrophoresis, the gel was visualized on a UV transilluminator (Kodak $G$ 100). A ladder marker with size of 100 bp DNA was run parallel for size comparisons to the PCR amplicons along with the test samples.

\section{Results}

During the period of study, a total of 18 duck plague outbreaks recorded from February 2011 to May 2012. Outbreaks were recorded in the District of Kamrup (11), Nagaon (4) and in Dhemaji (3). Out of 786 ducks 397 (50.50\%) were affected clinically and highest morbidity was recorded in duckling (57.78\%) followed by in adult ducks (36.22\%). In this study, a total of 79 suspected samples comprising of clinical (40) as well as post mortem (39) samples were collected. Various organs like liver, spleen, kidney, and esophagus were processed for confirmation of presence of DP virus in the samples. Antibody based test like sandwich ELISA (SELISA), agar gel precipitation tests (AGPT) and counter immunoelectrophoresis (CIE) tests were used for detection of duck plague virus antigen in clinical as well as postmortem samples. The standard protocol for sandwich ELISA adopted in the laboratory with incorporation of the preblocking step was found to be efficient in detecting duck plague virus antigen. Different blocking buffers $(5 \%$ skim milk, $5 \%$ Lactalbumin hydrolysate (LAH), $5 \%$ skim milk $+5 \% \mathrm{LAH}$ ) were tried for elimination of background color in S-ELISA. Blocking buffer containing 5\% skim milk was found to be highly efficient for elimination of background colour. A total 79 samples were processed, and 51.89 percent samples were found positive for viral antigen. Among the post mortem samples, the highest number of liver and the spleen tissue samples (81.82\%) showed the presence of DPV antigen followed by kidney $(63.64 \%)$ and oesophagus $(50 \%)$. In the clinical samples, whole blood $(38.89 \%)$ showed highest number of positive results followed by cloacal swab (27.28\%). In AGPT, precipitation bands were observed between different test antigens and the hyperimmune serum. A faint precipitation lines could be observed following 24 hours and distinct bands were seen after 48 hours of incubation at room temperature. The precipitate lines could be obtained with acetate (pH 5.6) and phosphate (pH 7.2) buffer systems incorporating additional $8 \% \mathrm{NaCl}$. It showed that the test could able to detect 12.82 per cent viral antigen in post mortem samples. None of the clinical samples (blood and cloacal sample) showed positive for AGPT. In tissue samples highest number of positivity was recorded in liver and spleen tissue (18.19\% each) followed by kidney $(9.09 \%)$. In CIE, both acetate buffer (pH 5.6) as well as tris-borate-EDTA (TBE) buffer (pH8.0) were used and positive result could be obtained in TBE buffer. A fine precipitation line was observed between the wells charged with the vaccine antigen/test antigen and hyperimmune serum. The precipitation lines were more prominent after 1 hour of storage at $4^{\circ} \mathrm{C}$. A total of 39 tissue samples (12.82\%) were found positive in the CIE. In PCR, extraction of viral DNA from clinical as well as from tissue samples using Qiagen DNA extraction kits showed the yield of viral DNA ranged between 80 to $120 \mathrm{ng} / \mathrm{\mu l}$. Total time required for extraction was about 1 hour. In positive test samples amplification of DP virus anticipated 446bp DNA dependent DNA polymerase gene against no amplification in negative template control [Fig-1]

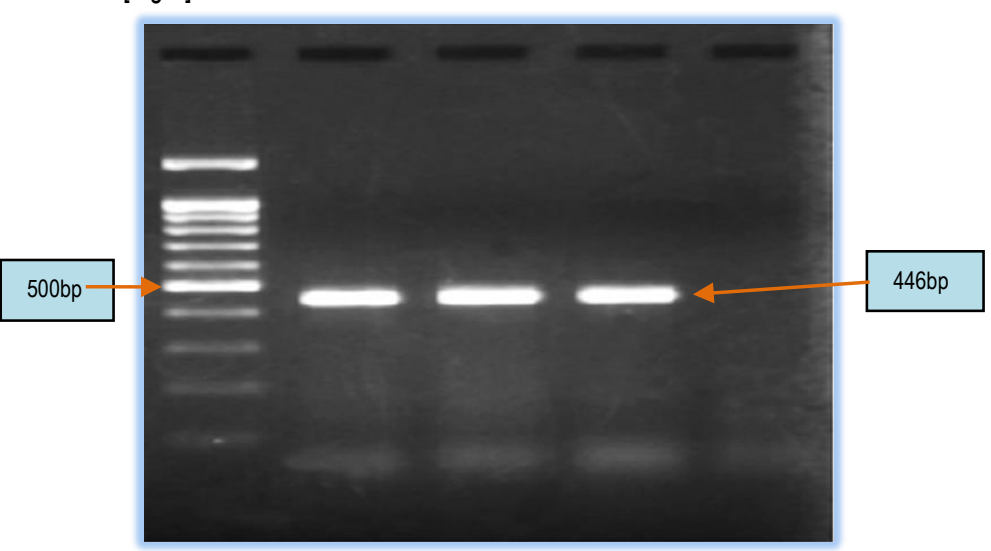

Fig-1 Electrophoresis analysis of pcr product of DNA Directed DNA polymerase gene of DP virus

$L=100$ bp ladder, $A=$ Known $D P$ vaccine virus $P=$ infected liver, $B=$ Whole blood, $N=$ Negative control

Total time required to complete the test including extraction of DNA is about 5 hours. Out of 79 samples $34(87.17 \%)$ post mortem samples and $34(85.00 \%)$ clinical samples showed positive for duck plague virus specific nucleic acid. Highest numbers of tissue samples showed positive for PCR were liver $(90.90 \%)$ and spleen $(90.90 \%)$ followed by oesophagus (83.33\%) and kidney $(81.81 \%)$. In clinical samples 88.87 percent was positive in whole blood and 81.82 percent was positive in cloacal swabs. The results of molecular (PCR) and antibody based diagnostic tests (S-ELISA, AGPT, and CIE) for detection of DPV is shown in the [Table-1]. 
Doley M.K., Das S.K., Barman N.N. and Baruah N.

Table-1 Detection of duck plague viral antigen from clinical samples and post mortem by PCR, AGPT, CIE and S-ELISA

\begin{tabular}{|c|c|c|c|c|c|c|}
\hline \multirow{2}{*}{\multicolumn{2}{|c|}{ Types of samples }} & \multirow{3}{*}{$\begin{array}{c}\text { Number of } \\
\text { samples tested } \\
22\end{array}$} & \multirow{3}{*}{$\begin{array}{c}\text { Number of samples } \\
\text { positive in PCR } \\
18(81.82 \%)\end{array}$} & \multicolumn{3}{|c|}{ Numbers of samples positive in } \\
\hline & & & & AGPT & $\mathrm{CIE}$ & S-ELISA \\
\hline \multirow{3}{*}{$\begin{array}{l}\text { Clinical } \\
\text { samples }\end{array}$} & Cloacal swab & & & $-V e$ & $-V e$ & $6(27.28 \%)$ \\
\hline & Whole blood & 18 & $16(88.88 \%)$ & $-V e$ & $-V e$ & $7(38.89 \%)$ \\
\hline & Sub Total & 40 & $34(85.00 \%)$ & 0 & 0 & $13(32.50 \%)$ \\
\hline \multirow{5}{*}{$\begin{array}{l}\text { Post } \\
\text { mortem } \\
\text { samples }\end{array}$} & Liver & 11 & $10(90.90 \%)$ & $2(18.19 \%)$ & $2(18.19 \%)$ & $9(81.82 \%)$ \\
\hline & Spleen & 11 & $10(90.90 \%)$ & $2(18.19 \%)$ & $2(18.19 \%)$ & $9(81.82 \%)$ \\
\hline & Kidney & 11 & $9(81.81 \%)$ & $1(9.09 \%)$ & $1(9.09 \%)$ & $7(63.64 \%)$ \\
\hline & Oesophagus & 6 & $5(83.33 \%)$ & $-V e$ & $-\mathrm{Ve}$ & $3(50.00 \%)$ \\
\hline & Sub Total & 39 & $34(87.17 \%)$ & $5(12.82 \%)$ & $5(12.82 \%)$ & $28(71.79 \%)$ \\
\hline \multicolumn{2}{|r|}{ Total } & 79 & $68(86.07 \%)$ & $5(6.33 \%)$ & $5(6.33 \%)$ & $41(51.89 \%)$ \\
\hline
\end{tabular}

Figures in the parenthesis indicate percentages

Comparing the efficacy of molecular and immunodiagnostic tests in detecting duck plague viral antigen showed that PCR could detect highest numbers $(86.07 \%)$ followed by S-ELISA (51.89\%), AGPT and CIE ( $6.33 \%$ each). All tests could detect DPV mostly in liver and spleen followed by kidney and oesophagus.

\section{Discussion}

DP causes significant economic loss in duck production in many places of India including Assam. The disease is wide spread has spread in many countries throughout the world causing heavy mortality in domestic ducks and wild mallards. Accurate diagnosis is DPV infection is a prerequisite for timely prevention and control of the diseases. In the present study, 18 numbers of outbreaks were attended in some places of the state of Assam. The morbidity rates of the ducklings were found higher as compared to adult ducks. Similar observation was also recorded in Assam by 7 where morbidity rate was found to vary from 49 to 100 percent and higher morbidity rate in ducklings compared to adult's birds. In the present study period comparatively, low rate of morbidity was recorded in adult which might be due to more number of adult duck's population prevailing in the region and duck might acquire natural immunity due to frequent exposure of natural infection or indiscriminate vaccination. Moreover, in the present study outbreaks were attended in small unit comprising of mainly the adult ducks. Various antibody based diagnostic techniques like AGPT, CIE and S-ELISA were used for detection of duck plague virus antigen in clinical as well as post mortem samples. In the present study, the S-ELISA protocol [4] was found suitable for detection of DPV antigen. In S-ELISA, different blocking buffer (5 \% LAH, 5\% skimed milk, $5 \%$ skimed milk+ 5\%LAH) were tried to use as blocking buffer. It was observed that 5 percent skimed milk with prebloking steps prior to addition of antigen eliminated nonspecific binding of other protein and thus improved the repeatability of the test. Comparing the per cent positivity from DP suspected clinical samples was found to be 27.28 and 38.89 per cent for cloacal swab and whole blood respectively. These observations were also reported [8]. They detected DPV antigen in the cloacal swab and blood after 48 and 96 hours of experimental infection respectively. Likewise, from suspected post mortem samples, the highest positivity (81.82\%) was recoded in liver and spleen followed by kidney $(63.64 \%$ ) and oesophagus $(50.00 \%)$. Some workers observed that in case of tissue the order of ability of detecting the virus could be arranged as follows-oesophagus, cloaca> brochi> liver> spleen> small and large intestine [4]. AGPT is a simple, user friendly routine diagnostic test used in field for diagnosis of DP virus antigen, in which the precipitation lines could be obtained with acetate (pH 5.6) and phosphate (pH 7.2) buffer systems with additional 8 percent $\mathrm{NaCl}$. This finding agrees with some other workers $[9,10]$. Similarly, CIE is a modification of AGPT for providing comparatively rapid diagnosis. However, both the test posesses disadvantage of sensitivity. In the present study, out of 39 tissue samples comprising liver, spleen, kidney and oesophagus, only 5 samples gave positive reaction in CIE. These findings are in agreements with the findings of earlier workers $[9,10]$. For detection of DPV nucleic acid, DNA directed DNA polymerase gene was targeted in the present study. Various workers had targeted the gene because of the highly conserved nature of the gene $[11,12]$. The targeted gene is nonstructural gene which have open reading frame (ORF) of UL-30 which play many roles like DNA replication, DNA replication-recombination and DNA cleavage-encapsidation. This region is widely used for phylogenetic analysis between alpha-, beta and gamma herpesvirinae [13]. The DNA polymerase gene can also be used for differentiating diagnosis from the other avian herpesvirus infection like Mardivirus virus and Iltovirus. In the present study, PCR technique was used for detection of DPV both in postmortem and clinical samples. In postmortem samples, it was observed that in PCR out of 11 samples tested each from liver, spleen and kidney, 90.90 percent were positive in liver and spleen and 81.81 percent positive for kidney. Similarly, $5(83.33 \%)$ out 6 samples of oesophagus showed positive reaction in PCR technique. There seems to be no reports of used of PCR technique for diagnosis of duck plague virus infection from post mortem samples. The present findings reveal that PCR techniques may be have great used for diagnosis of DP virus infection in tissues samples collected from suspected cases of dead birds. Considering, the small number of samples, further study involving large number of samples is highly recommended. In clinical samples, out of 22 cloacal swab $18(81.82 \%)$ showed positive reaction whereas out of 18 samples, $16(88.87 \%)$ showed positive reaction. Comparative efficacy of molecular and antibody based diagnostic techniques for detection of DPV antigen showed that PCR is more efficient on post mortem tissue as well as clinical samples as it could detect presence of DPV in $87.17 \%$ and $85.00 \%$ of the samples respectively. Various workers compared ELISA and PCR and opined that PCR can be regarded as the 'gold standard' for duck plague diagnosis [14]. However, S-ELISA could detect DPV antigen in $71.79 \%$ and $32.50 \%$ of the postmortem and clinical samples respectively. The combined positivity of PCR and S-ELISA in post mortem tissues as well as in clinical samples was found to be $45.56 \%$ for detection of Duck virus. Similar type of finding also reported [15]. The less sensitivity of the serological tests compared to PCR may the fact due to difference in target. In serological protein antigen were targeted which is easily degradable as compared to genomic DNA for PCR assay. Serological tests also failed to detect low concentration antigen.

\section{Conclusion}

Duck plague or duck viral enteritis is an acute and contagious viral disease of ducks, geese swan and other waterfowl cause significant economic losses in duck husbandry due to decrease in egg production, condemnation, and mortality. Timely diagnosis of this disease may great help in taking preventive measures for the farmers and policy makers. Comparative efficacy of molecular and antibody based diagnostic techniques for detection of DPV antigen showed that PCR is more efficient on post mortem tissue as well as clinical samples. PCR can be regarded as the 'gold standard' for duck plague diagnosis. Among the antibodybased techniques S-ELSA was found more sensitive than the AGPT and CIE. In terms of sample liver and spleen was found to be most suitable tissue samples for detection of viral nucleic acid and antigen. In cases of clinically affected duck whole blood was found to be more suitable than cloacal swab for diagnosis of the disease. However, due to simplicity of collection, cloacal swab may be the choice of sample for large flock.

Application of research: The diagnostics methods will help in monitoring as well as preventive measures for further spread of duck plague disease.

Research Category: Microbiology and immunology 


\author{
Abbreviations \\ ${ }^{\circ} \mathrm{C} \quad$ : Degree Celsius \\ ul : Micro litre \\ AGPT: Agar Gel Precipitation Test \\ bp : Base pair \\ CAM : Chorio-Allantoic Membrane \\ $\mathrm{CIE}$ : Counter Immunoelectrophoresis \\ DNA : Deoxyribo nucleic acid \\ dNTP's : Deoxy nucleoside triphosphate \\ DP : Duck plague \\ DPV : Duck Plague Virus \\ DVE : Duck Virus Enteritis \\ EDTA : Ethylene Diamine Tetra Acetic Acid \\ g : Gram \\ HRPO: Horse Radish Peroxidase \\ LAH : Lact-Albumin Hydrolysate \\ $\mathrm{MgCl}_{2}$ : Magnesium Chloride \\ $\min$ : Minute \\ $\mathrm{NaCl}$ : Sodium Chloride \\ ng : Nano gram \\ OD : Optical density \\ ORF : Open Reading Frame \\ PCR : Polymerase chain reaction \\ Pmol : Pico mol \\ sec : Second \\ S-ELISA: Sandwich Enzyme linked immunosorbent assay \\ SM : Skim Milk \\ TBE : Tris borate EDTA \\ UV : Ultraviolet
}

Acknowledgement / Funding: Author thankful to Department of Veterinary Microbiology, College of Veterinary Science, Assam Agricultural University, Khanapara, 781022, India

\section{Research Guide and Major Advisor: Dr S. K. Das}

University: Assam Agricultural University, Guwahati, 781022

Research project name or number: MVSc

\section{Author Contributions: All author equally contributed}

Author statement: All authors read, reviewed, agree and approved the final manuscript

\section{Conflict of Interest: None declared}

Ethical approval: This article does not contain any studies with human participants or animals performed by any of the authors.

\section{References}

[1] Leibovitz L. (1991) Diseases of Poultry., gth Edition, lowa State University Press: Ames, lowa, USA.

[2] Kaleta E.F. (1990) Avian Pathol., 19, 193-211

[3] Sandhu T.S. and Shawky S.A. (2003) Diseases of Poultry, 11, 354363.

[4] Hung D., Phuck K., Trung T., Huong N. And Morrissy C.J. (2004) ACIAR Proceedings No., 117.

[5] John K., Sarma K., Boro B.R., Das S.K. and Mukit A. (1989) Indian Jour.of Anim.Sci., 60, 615-617.

[6] Office of International des Epizooties, OIE (2008b) OIE Terrestial Manual, 1(14), 190-217.

[7] Chakravarty A.K., Dutta B.M., Mukit A., Boro B.R. and Bhattacharya M.L. (1980) J. Res. Assam Agric.Univ., 1, 72-78.

[8] Phuc K.V., Hung D., Tu T.D., Trung N.T., Morrissy C.J. and Prichard
L.L. (2004) ACIAR proceedings No,117.

[9] John K. (1988) Adaptation and attenuation of locally isolated strain of duck plague virus in embryonated eggs, M.V.Sc. Thesis submitted to Assam Agric. Univ. Guwahati, Assam.

[10] Sharma K. (1992) Studies on antigenic characterization and immune response of locally isolated strain of Duck plague virus in embryonated eggs. PhD Thesis submitted to Assam Agric. University., Guwahati, Assam.

[11] Xuefeng Q., Xiaoyan Y., Anchun C., Mingshu W., Dekang Z. and Renyong J. (2008) Avian Pathol., 37(3),307-310.

[12] Mondal B., Rasool T.J., Ram H. and Mallana S. (2010) Biologicals, 38, 401-406.

[13] Thureen D.R. and Keeler C.L. (2006) J. of Virol., 80(16), 7863-72.

[14] Hansen W.R., Nashold S.W., Docherty E., Brown S.E. and Knudson D. L. (2000) Avian Dis., 44, 266-274.

[15] Pritchard L.I., Morrissy C., Van P. K., Daniels P.W. and Westerbury H. A. (1999) Vet. Microbiol., 68(1-2),149-156. 